\title{
Correction to: Does Group Size Affect Students' Inquiry and Collaboration in Using Computer-Based Asymmetric Collaborative Simulations?
}

Meeli Rannastu, Leo Aleksander Siiman, Mario Mäeots, Margus Pedaste, and Äli Leijen

\begin{abstract}
Correction to:
Chapter "Does Group Size Affect Students' Inquiry and Collaboration in Using Computer-Based Asymmetric Collaborative Simulations?" in: M. A. Herzog et al. (Eds.): Advances in Web-Based Learning - ICWL 2019, LNCS 11841, https://doi.org/10.1007/978-3-030-35758-0_14
\end{abstract}

The original version of the chapter 14 was previously published non-open access. It has now been changed to open access under a CC BY 4.0 license and the copyright holder has been updated to 'The Author(s).' The book has also been updated with the change. 